\title{
Locating the Child in the Curriculum: Teachers' Conceptions of Student Individuality
}

\author{
Steven Katz and Leanne Foster \\ Ontario Institute for Studies in Education/University of Toronto
}

\begin{abstract}
In this paper, we use the folk pedagogical construct to explicate the dilemma of teachers being poised between mandated curricula standards and the individual children they serve. By reference to a series of interviews with practicing teachers, we show that attempts to locate an individual child within the curriculum are mediated by the larger structural contexts within which the practices of teaching are inscribed. Teachers' conceptions of student individuality are shown to assume a trait-like explanatory posture with individual differences being explained in terms of "kinds" as opposed to "degrees". The resulting dynamic is one of an assumption of categorical homogeneity amongst members of particular "kinds", as well as a substitution of behavioral and affective outcomes for cognitive ones when individuals are considered in relation to the class.
\end{abstract}

\section{Introduction}

Each November, our preservice teacher candidates return to the Faculty following a five-week placement in the field-based setting of a school. The result is a pedagogical context imbued with a previously unseen character in which candidates simultaneously wear the institutionally sanctioned hats of both teacher and student. Early ideals give way to more urgent pragmatics, as the student teachers find themselves grappling with what might best be described as a series of dilemmas. Such dilemmas, emergent from the candidates' first foray onto the practical landscape of education in their developing professional roles, assume a variety of postures. Windschitl (2002) puts forward a four-fold taxonomy of dilemmas that characterize the kinds of emergent concerns referenced here. The first two categories, conceptual and pedagogical dilemmas, highlight the challenges in grasping the underpinnings of theory and then importing this understanding into a classroom context. The third kind of dilemma, cultural, involves becoming cognizant of the culture of a given classroom and questioning what is implicitly and explicitly valued. Finally, political dilemmas describe how

Dr. Steven Katz, faculty member in Human Development and Applied Psychology at OISE, University of Toronto, specializes in the psychological foundations of human performance and the design of data-driven systems for organizational planning and improvement, and has received the Governor General's medal for excellence in his field.

Leanne Foster is a doctoral student in the Department of Theory \& Policy Studies in Education at OISE, University of Toronto. 
teachers are situated within a larger context of organizational praxis as given by the school, the community, the district, the state or province, and, in some cases, the nation.

Throughout our years of involvement in preservice teacher education, we have come to observe that while the nature of some dilemmas appears transient due to their specificity, others are more stable and enduring in their generality. The pendulum between whole language and phonics, for example, continued to swing back and forth before settling somewhere in the middle, as did the debate between the movements of outcomes and objectives. Conceptions of "best practice" change over time, as do the compositions of curricula and community demographics, thus changing the nature of the dilemmas to which they give rise. On the other hand, feelings of disconnect between Faculty-espoused theory and practical implementation continue to endure, as do the calls for what might best be described as a classroom management solution despite the impossibility of such issues.

In this paper, we focus on one particular enduring dilemma. It is a dilemma that has been brought to us time and again by our students as they have returned from the field, though it has increased in prominence over the past decade as a result of a broader contextual tide. We are referring here to the perennial challenge of teachers having to meet both the demands of a fixed school curriculum and the needs of the individual children who make up a class, with their varied understandings, interests, and backgrounds. We briefly explicate the catalytic context referenced above, before turning to an explication of the said dilemma. We accomplish the latter first by way of theoretical deconstruction and subsequently by reference to a series of extensive interviews with teachers who experience the dilemma every day in their professional lives.

\section{A Context of Intensified Standards}

In describing the ascendancy of what they refer to as the "age of accountability", Earl and Katz (2003) explain that there was a time in education when decisions were based on the best judgments of the people in authority. School and district leaders, as professionals in the field, were assumed to have both the responsibility and the right to make decisions about students, schools, and education more broadly. They relied on their tacit knowledge to formulate and execute plans. In the past several decades, a great deal has changed and accountability has become the watchword of education. The key to progress in this milieu, as Fullan (1997) states, is in the development of a system of external standards and to establish means for the utilization of this information to bring about improvement.

Hargreaves, Earl, Moore and Manning. (2001) characterize the noted shift in terms of the emergence of what they refer to as "the new orthodoxy". The new orthodoxy, they explain, is characterized by centralized, systemic mandates for both curriculum and assessment. In Ontario, Canada, for example, a curriculum of essential learning outcomes, grouped into four general program areas, gave way to a series of "back to the basics", subject specific documents. The thrust of this new curriculum endorsed the notion of measurable outcomes in reporting 
requirements, provided detailed specific expectations for student achievement, and introduced a standard report card for use province-wide. It is our contention that this context of intensified standards functions to underscore the referenced dilemma between respecting both the specificity of the knower (child) and the generality of the known (curriculum).

\section{The Individual Within the Class}

The identification of the dilemma that is reflective of the challenge of respecting both child and curriculum has certainly not gone unacknowledged in the teacher education literature. Indeed, the very current educational psychology textbook (Sternberg \& William, 2003) that we use in the preservice class referenced earlier starts the chapter on cognitive development with a hypothetical scenario of a teacher struggling to meet the needs of her diverse "class" of students. As one might gather from the placement of the scenario in the textbook, the authors classify the dilemma as one of developmental variability. That is, they suggest that the lock step, age-grade structure of formal schooling is far narrower than the developmental range on which it is predicated. While we do not disagree with this proffered explanation, we would suggest that the practical manifestation of the dilemma is one that is more of "kind" than of "degree".

Katz (2002) points out that a close inspection of the title of Dewey's (1902/1966) seminal work, The Child and the Curriculum, reveals an attempt to link the two defining ingredients of schooling. Dewey believed that the child and the curriculum should be considered as defining opposite points of a single continuum. The task of the educator, then, is to orient the natural abilities and interests of the child in the direction of the formal curriculum.

Despite such unification efforts, Katz $(1998 ; 2000 ; 2002)$ has argued that a pervasive dualism between child and curriculum continues to reside on the practical landscape of formal education. This bifurcation, he suggests, is supported by orthogonal definitions of competence that share space in the workings of teachers' professional lives. Different conceptions of what it means to be competent entail a different set of pedagogical moves aimed at enhancing that competence. It is this divergence in pedagogies that allows us to identify what Olson and his colleagues (Olson \& Bruner, 1996; Olson \& Katz, 2001) have called alternative folk or intuitive pedagogies - cohesive sets of beliefs about learners' minds and knowledge that guide and structure our pedagogical practices.

In a series of earlier papers (Katz, 2002; Katz, 2000; Katz, 1998; Katz, Earl \& Olson, 2001; Olson \& Katz, 2001), we argued that the specific nature of the intuitive, yet orthogonal, definitions of competence that underlie the child/curriculum duality are, in fact, given to us by these two very different entities, namely the "child" and the "curriculum." This earlier argument advanced the notion that the formal curriculum, whether couched in a language of outcomes, expectations, or objectives, typically delineates the contents of our cultural store. When this is our concern, competence is generally defined in terms of the possession of knowledge, be it declarative or procedural. The popular epistemology at work here is an entity view of knowledge. Knowledge 
is considered to be certain and permanent and capable of being judged as right or wrong (Kuhn, 1999; Perry, 1970; Schommer, 1994). Truth is authenticated by the appropriate authorities, be they persons or texts (Baxter Magolda, 1992; Belenky, Clinchy, Goldberger, \& Tarule, 1986; King \& Kitchener, 1994; Kuhn, 1999).

The aforementioned epistemological conceptions find practical manifestation through the practice of classroom teaching. Teaching, in a known-centred competence model, appears as telling or showing. Learning becomes about remembering (Earl \& Katz, 2000; Olson \& Katz, 2000). The fit between what is told (or shown) and what is remembered is gauged via the mechanism of assessment. This process of teaching and assessing learning can be in the context of formal testing or through the more indirect avenue of classroom discourse. The discourse pattern at work here is one that proceeds through teacher questioning, but rather than honest requests for information, teachers are typically aware of the answers they are looking for (Applebee, 1996; Heath, 1982).

At the same time as they are being directed by the knowledge and demonstration requirements of the formal curriculum, teachers are also confronted with the reality that it is individuals, not classes, that learn (Clay, 1996; Thomas, 1992). Thus, they are also guided by the constraints given to them by the individual students, with their varied interests, backgrounds and understandings, who constitute their classes. The applicable competence definition at play here is one conceptualized in terms of each student's efforts at making their own meaning. Epistemologically, then, knowledge is interpreted subjectively and truth assumes a transient and personal quality (Chandler, Boyes \& Ball, 1990; Kuhn, 1999; Perry, 1970).

As we move from epistemology to pedagogy, we find sets of teaching practices designed to create opportunities for sharing beliefs through collaborative discourse and promoting the perspective of learning as subjective sense-making (Earl \& Katz, 2000; Olson \& Katz, 2000). Metaphors given to us by pedagogical initiatives such as "curriculum as conversation" (Applebee, 1996) and "communities of learners" (Brown \& Campione, 1994; Rogoff, Matusov, \& White, 1996) explicate the point. In the assessment arena, the so-called "innovative" assessments (Earl \& Cousins, 1996; Wilson, 1996) assume primacy as portfolios and other self-assessment vehicles promote the interpretation process.

The segregation of child and curriculum suggested by the folk pedagogical construct may strike the reader as anachronistic and indeed it should. What is important to remember, as Katz (2002) reminds us, is that the epistemologies that colour the landscape of formal education are the "folk" or popular ones. They typically assume an implicit posture, perhaps only to be reconstructed from their consequent pedagogies. An extensive body of research, replete with a set of methodologies, examines these types of epistemological beliefs. Its findings suggest that few people ever reconcile the qualitative rift between "knower" and "known" (c.f. Baxter Magolda, 1992; Belenky et al., 1986; King \& Kitchener, 1994; Kuhn, 1999; Perry, 1970). Just how this paradox, or dilemma, is 
manifested in the contexts of actual teacher practice is the subject of the present paper. In the pages that follow, we offer an empirically derived account of how teachers conceptualize the individual with respect to the class.

\section{Method}

The study referenced here involved twelve middle-years teachers, each of whom was interviewed for approximately 90 minutes. The methodology was informed by Strauss's (1993, 1996) distinction between teachers "espoused" and "in-use" pedagogical content knowledge. The former refers to teachers speaking about how they would teach in a particular situation, while the latter occurs when teachers actually teach, in practice. Polanyi (1958), like James (1830/1950), reminds us that practice results in the formation of tacit, as opposed to articulate, knowledge. Thus, from a methodological standpoint, asking a direct question such as 'What is your philosophy of teaching?' may or may not be indicative of actual experience. Instead, the questions and probes in the semi-structured interview schedule asked teachers to describe what they do in concrete terms, providing a context for the emergence of what Stanovich and Jordan (1998) refer to as "grounded belief".

Specifically, participants were first asked to provide a concrete illustration of a class-directed lesson. Thereafter, they were asked to provide a descriptive account of a specific child who, although not formally identified, required some instructional modification/accommodation/adaptation. Finally, the participants were questioned explicitly about their own insights into the requirement of having individual children reach a fixed set of goals.

The interviews were tape-recorded, transcribed, and imported into Folio Views 4.1 information management software for analysis. For each participant, we compared and contrasted the answers given in response to questions about the class and the individual in the areas of lesson goals, goal origins, pedagogy, outcomes, and assessment and reporting practices. Thereafter, these teacherspecific responses were considered in relation to one another (Glaser \& Strauss, 1967 ) in order to identify broad patterns across responses of the participant group. In addition, the participants' responses to questions about conceptions of individuality, and about explicit beliefs about the feasibility of diverse classes reaching fixed goals, led to the creation of two more categories: "Conceptions of Diversity and Individuality" and "The Question of Feasibility". The relevant categories that organized the findings according to the order in which they are presented in the next section, then, are as follows:

1. Conceptions of Diversity and Individuality

2. Identified Individuals

3. Identifies Groups

4. Individual vs. Class

Goals

Goal origins

Pedagogy

Outcomes

Assessment and reporting

5. The Question of Feasibility 


\section{Findings}

\section{Conceptions of Diversity and Individuality}

While it is true that the ideal manifestation of the achievement of fixed knowledge would appear in student performances characterized by predetermined means and zero variances (Hacking, 1996), diversity amongst learners in their achievement of these fixed goals is conspicuous. Olson (1999) points out a way in which such diversity is commonly reconciled through psychological theory; in particular, the psychology based on intelligence and personality testing that serves primarily to predict and explain away the differential outcomes of schooling. He identifies a stance to the problem of diversity known as Individual Difference. Individual Difference proceeds by classifying people on the basis of values on particular dimensions or traits. It is trait ascription that characterizes much of teacher talk today as they attempt to account for classroom performance variance on the basis of particular dimensions like "persistence", "impulsivity", "giftedness" or "hyperactivity" (Olson, 1999). Although such characterization is almost irresistible, it is also misleading especially when such traits are concretized into entities. Intelligence, for example, began as an abstract relation between strategies and tasks but quickly became a possession, or perhaps more accurately, a capacity with implications for competence.

An alternative conception of diversity to the aforementioned comes to us from Dewey who saw knowledge as emerging from a process of interpretation and clarification of meanings related to various aspects of experience in the world (Dewey, 1938). Along with this emphasis on interpretive sense-making came a psychology of doings that stood in contrast to the psychology of happenings (Olson, 1999). Dewey argued that while trait psychology proffered causal mechanisms that explained behaviour in terms of what happened, a preferable alternative would be to explain behaviour in terms of what agents, including learners, were doing or trying to do. Thus, the shift is from causes to reasons, from persons as passive respondents to persons as intentional agents. Children are seen as acting in accordance with their beliefs, desires, hopes, and intentions, that is, their mental states. Diversity is a central and acknowledged feature of an intentional psychology wherein the notion of variances replaces that of a desired mean. Deviations from predetermined norms are not aberrations but rather are to be expected.

Of the two stances on the issue of diversity and individuality described above, it is the former, the trait version, to which the participants in this study most conformed. What is surprising is that despite the explicit encouragement to select an individual who was not formally identified for the purposes of the interview exercise, all of the teachers did so anyway. That is, to be considered as standing apart from the generality of the class was to be assigned (usually formally) to a preexisting category. It is this practice that reflects a trait, rather than an intentional, posture of diversity and individuality. The selection was of a person as exemplifying a "kind" (Olson, personal communication, 2001). 


\section{Identified Individuals}

When asked to describe the selected individual considered to be distinct from the class, several of the teachers referenced institutionally assigned labels or categories as follows:

She has a communication disability. She is very, very weak [and] struggles with everything.

OK, my ADHD student who's on medication.

I won't use his name. We just finished the IPRC [Individual Program

Review Committee] process with him. He's identified behavioral now.

\section{Identified Groups}

Other teachers endorsed the categorical view of individuality in a slightly different, but perhaps more revealing way. Specifically, there was an assumption of homogeneity insofar as members of a particular category were concerned, and certain teachers did not differentiate between individuals within the same group. For example:

I have three very, very low Math students in this class.

I've got all ten of [my identified students] in mind.

They're all modified basic students... Every one is a Special Education student.

It is important to note that the conceptualization of individuals in trait terms as suggested by the interview excerpts given above is likely not the outcome of an autonomous decision making process on the part of teachers. Teachers, as professionals, participate and find membership in larger institutional structures that legitimate and sanction the existence and use of such categories as Educable, Identified, Modified Basic, and ESL. Indeed, as one participant put it, teachers are obliged to proceed in keeping with such systemic requirements in order to pedagogically differentiate an individual from a class:

[Name], who's the new head of Special Ed. this year, said, "You know what? This isn't fair. Because we are getting the funding for these kids that are Special Ed. and yet we're modifying and accommodating for these ones that have not been tested and they're passing with 60s and 70 s and really they shouldn't be. They need to be assessed through psycho-ed., and they haven't been."

In global terms, the categorical conception of individuality held out by teachers has the metaphoric effect of focusing such descriptions at the tail-ends of the particular distribution. Moreover, the concretizing of such labels into entities means that the distinctions that are made between classes and individuals are more a matter of kind than degree. The end result is that what initially appears as 
the tail-ends of a single distribution is perhaps better characterized as an entirely different one altogether. Specifically, the teachers in the study ascribe qualitatively different definitions to the notions of Goals, Goal Origins, Pedagogy, Outcomes, and Assessment and Reporting where individuals versus classes are concerned.

\section{Individual vs. Class}

Goals.

In discussing the goals of a lesson for particular individuals in relation to the whole class, three possibilities emerged from the teacher interviews. For a minority of the participants, the goal of the lesson was the same for both the identified individual and for the class:

They [the class] need to know that there has been a lot of progress made in terms of [Native Canadian's] rights, and how they're educated today, and things like that... She [the identified student] is expected to do the same thing.

Okay. So this morning's lesson...[we] wanted them to have a sense of wheels, ...axles....and gears, okay? What do they need to make these things move....My ADHD student who's on medication,...the expectation for this child is still the same as for the others.

For more of the teachers, the goals were generally the same but they were expected at a reduced level or at a lower standard where the individual was concerned. For example:

Most of the kids...I would expect to begin to really make that logical connection [between mathematics and probability] and begin to see there's a pattern and all those other things. These two or three or four kids I have, all I want them to do is begin to see. Because they won't apply those in all kinds of situations... So no, my goal would not be to move them that far.

For the majority of participants, however, the specification of the goals for the selected individual(s) took a qualitatively different orientation from those proffered for the class. Specifically, while a reduced level or standard may have been noted as given above, this was in addition to some social/behavioral goal that related directly to the individual's categorical identification and assignment:

[The class goal] was to write a narrative piece, and the [choice] of perspective was your own... [For this student the goal was] social skills. ... They were social skills for him to participate as an equal member in the team.

For the rest of the class [the goal] is basically to get your sewing skills. For them [the kids in the educable program], it's don't hurt anybody else [and] just be able to sit still. 


\section{Goal origins.}

Given the differential nature of the goals described by teachers for both the individual and class respectively, it is perhaps not surprising that goals were ascribed to equally divergent places of origin. The goals for the class were typically derived from the formal curriculum, that repository of expected "knowings" and "doings". For example:

[The class goals come] from the curriculum.

[The class goals] come straight out of the Science curriculum - the new Ministry document.

The rubric will be established for the expectations according to the Ministry document.

Turning our attention to the individual category, we find an alternative set of goal origins identified as arising from the teacher, a resource person, or the child's Individual Education Plan (IEP). For instance:

[His goals come from me for] my survival... You know, survive this kid, the presence of this kid in the classroom and make it as positive for him as possible, as positive for the other kids as possible as well without major disruption.

In my head. I don't know, I'm just... It's just probably, basically what they can do, accomplish.

It's from his IEP... Finishing, getting things done, handing things in as close to on time as possible.

\section{Pedagogy.}

The emergent pedagogical pattern spelled out in lesson descriptions for the class was one in which the teacher showed/modeled the expectation(s), and then transitioned into student independent work with opportunities for teacher feedback. The following examples illustrate this pattern:

It was a very directed lesson. I gave them a script, a narrative, and I put it on the overhead. I read it to them. They followed it on overhead as we were going through it, and we took a section of that and then we wrote it as a script....We wrote a script as a class. Then the next lesson, we read the story together, again it was a narrative, and I asked them to go back and... as a group, write the script for this piece... And then the third step in the writing was, "All right, we're going to read the same thing and you're going to do it individually." And each time along the way, when they were doing any kind of writing as a group, I was giving feedback.

I'll sit down at a sewing machine and I'll describe how they have to set it up, and what they have to do, and then I'll ask if they understand. 
And then they go and they do it and they bring back what they've done, and I see if they understood before they can move on to the next set.

As the teachers in the study turned their attention to particular identified individuals, the immediately preceding pedagogical pattern took on a different character. The dominant theme was that of reduced independence on the part of the learner. Teachers purported to read, scribe, or highlight for the selected individuals, as well as to make structural adjustments that were given in terms of altered time and pace requirements. For example:

The first thing I had to do was read it for her while she followed along. And then we went back and I took a highlighter and I highlighted the most important points from the text. And then I left her because I thought, "I bet you she's going to copy it word for word, everything I've highlighted." And sure enough... that's all she was doing.

So with him I scribe for him a little bit. He told me his story. I paired him up with a stronger student.... What else did I do with him? Oh, I put him on the computer very quickly in the writing process, so he, all he did was write on the planning sheet....With him it's more of a policeman kind of role. Um, often it's a policeman role, control, let him know when he's being too loud. So yeah, my main job with him is a lot of cop, a lot of control, and as much positive feedback as we can muster from time to time.

I'm making sure they stay on task, and that they're not goofing around, and that they're not breaking sewing machines, and they're not hitting other students, and that sort of thing. It's more of a, they're very behavioural, so more sort of a police watch on these kids, and making sure they're always on task and they always have something to do.

\section{Outcomes.}

For the class, the teachers reported the outcome of their chosen lessons in terms of success relative to the advertised goal. This reporting took the form of interview comments that alluded to notions like "getting it" or "doing well", but they also often operationalized success in the measurable terms of grades and levels. For instance:

Well, they're all pretty much meeting, you know, Ministry expectations. So if you look at the last report... there is a range from Cs through As, as far as academic ability goes.

Seventy percent of the class is level two and three, and ten percent are level four, and another twenty percent are level one or worse.

None of the performances were at all what I was expecting for them to be able to accomplish...Quite a few of them got zero, or close to zero, out of five because it just, they didn't, they lost sight of what they were supposed to be doing. They didn't write a script that convincingly, and 
they didn't play the roles convincingly. ...I told them that their acting scores were terrible and their play writing was - they didn't accomplish the goal.

Earlier we reviewed the relationship between reported class and individual goals. Specifically, we noted that the proffered goals for selected individuals were either: a) the same as those for the class; b) essentially the same as those for the class but at a reduced standard; or c) changed in favour of a socio-behavioral focus. Given this profile, one might expect to find a similar parsing of individual outcomes, but this, however, was not the case. The teacher comments on the individual student outcomes assumed a strictly behavioral/affective orientation. Talk of the particular students feeling "good" and "successful" was supplemented with references to task "completion" and "engagement". Unlike the class-wide outcomes that were discussed relative to a (usually curricular) standard, the individual outcomes assumed a child-referenced posture:

They [the three "low" students] enjoy it because they're very successful. I can put on their report, you know, that they got seventy something. Now it's modified and it's all, you know, - but the kids see a decent score... And our bottom-line with these kids is life-skills.

Yeah, I was pleased. I think they [the two identified students] caught on better than I perhaps imagined that they would initially, or more quickly than I thought they would.

...The fact that he completed it. I guess that's the main part with this student. We didn't have a yelling and screaming match about not being able to do it, and not completing it. The process let him complete an assignment to its end and the expectation of feeling the goal had been met, of "I did it, I finished a novel..."

\section{Assessment and reporting.}

The prototypical assessment and reporting practices explicated by the teachers in the context of whole-class interactions involved providing students with the relevant expectations, often by way of a rubric, and then testing and marking against the expected criteria. Employing numerical and alphabetic categories for the purpose of reporting student achievement delimits the role of "teacher as accountant" (Wilson, 1996). The task here is to provide a common basis of comparison so that each child appears to be treated as fairly as every other child. Indeed, this role is intimately bound to that of "teacher as reporter" (Wilson, 1996), in which the teacher is required to keep organized records in order to expedite the process of gathering, interpreting, and relaying information for outside communication. It is an amalgamation of these two roles that characterized the reported class-wide assessment and reporting practices proffered by the teachers:

You know, you're doing this little presentation; this is what the criteria are, you know, the old rubric and stuff. This is what we'll be looking 
for. Have you explained the parts of your machine? Check, check, check. Have you explained the functions right? And have you used interesting words...?

It's numbers - out of 5 in most cases, except for the theme which was out of 10 and the acting which was out of 10. And staging was 5 and, what was the other one, oh script was out of 10 . It was out of 35 . So it was 35 marks on that... Formal assessment is about coming up with a the mark for the report card, and to satisfy the parents about what children are doing, and to satisfy the children's need to know how they're doing, and to make sure they are achieving what I think they are achieving. Rubrics are a good idea. They focus my attention on, on different aspects, and they give me a much better idea of whether I'm accomplishing specific goals... and it gives the child guidance too.

The individual-specific assessment and reporting practices explicated by the teachers mirrored the general pattern of differential standards and studentspecific reference points outlined in the preceding conceptual categories. Revised standards and different criteria, often keyed to lower grade levels, approximated the measure against which the success of "individual" outcomes was determined. Moreover, Wilson's (1996) assessment role of "teacher as mentor" emerged insofar as teacher judgments about the particular student's progress and growth were referenced relative to the self. Such assessments, Wilson notes, are often not recorded and assume an anecdotal character. Examples of these two "individualized" patterns of assessment and reporting practice emerged as given in the following prototypical excerpts:

[Name of Instructional Assistant] does the assessment [for these three kids] and it's not based on a rubric... It's very anecdotal... They're sitting in a Grade 8 class but they're doing Grade 6 work. And it'll say on the report, you know, it's a modified program and on their Individual Education Plans I think it says Grade 6.

When I marked the test...the first page of it was really well done and I made a note about that... as I went to the second paper where he was beginning to struggle I wrote him little notes like, "Oh, you got this one", "This was a hard one", "Good for you", you know, these kinds of things. But again, it's a much more individualized kind of thing.

I'll go through it the first time and see where he stands according to everybody else, you know, all together... Then I'll go back and look at where he is, himself, and at the teacher's discretion per se, see where he connects with what I know he has done in the past.

He's on an informal Individual Education Plan, so we can't...evaluate him by Grade 6 expectations. He's evaluated by expectations at a different grade level. So basically I look for what he has got in here at a Grade 3 level. I don't know what a Grade 3 level person looks like, but you know... Well, I do, but it's not very valid so I also had the Special Ed. resource teacher look at it. She made her assessment on 
it....For Grade 6 he would have an R [for Remedial]. And at Grade 3 he would have been a Level 2. So we marked it down as a Level 2. And because it's a modified program, that's where it goes.

\section{The Question of Feasibility}

Having spelled out teachers' conceptions of the individual in relation to the class - of the child in relation to the curriculum - in the five aforementioned organizing categories of actual practice, we are now in a position to entertain the participants' direct responses to the said dilemma. Subsequent to the interview task that elicited the findings presented above, the teachers were asked a question that is arguably the definitive pedagogical task of formal schooling. That is, they were asked if they thought it feasible for all children in a class to reach a common set of goals and expectations as set out, and indeed required, by the formal curriculum. The resounding and unanimous answer, as reflected by the following exemplary set of sample responses, was no:

It's - well it's not [feasible]! Everyone's an individual. There are some 20 or 30 odd little faces looking at me and they all come with different backgrounds, and different strengths and weaknesses, and that's a tough haul! There are kids that - there's just no way they're going to be able to do some of the stuff in either Math or Language or whatever. Um, yeah, no it's not, it's just not feasible.

We're expected to meet a certain expectation. I don't know how realistic it is sometimes. ...Unfortunately, well fortunately, kids don't all learn the same way and at the same time. And I kind of play with the expectations, I will admit. It's not going to cost me my job now [because I'm retiring at the end of this year], but eventually it would, if I didn't say, "This is the expectation. You'll all learn it. And this is how you do it."

Oh boy! You want a political answer or you want the real answer? The [real] answer is not a chance, a snowball's chance in the proverbial hell of it ever happening. No, these kids, adolescents, are at such different levels, cognitively and in every other way. ...And some children are there in Grade 6, some won't be there until the end of Grade 9. And it's sheer folly, and setting ourselves up for tremendous failure, if we say every child shall reach this at this age. There's no such thing as a lock-step curriculum when you're talking about children. The government's wrong. It's not going to happen.

The feasibility question and the associated participant responses endorse the practical reality of the folk pedagogical dilemma. Indeed, at the level of explicit talk teachers recognize the challenge inherent in being poised between the mandated objective standards and the children they serve. In this paper, we have taken a step in understanding the route to connecting the child and the curriculum by presenting and discussing empirical evidence reflecting teachers' conceptions of individuality in the collective context of the classroom. What emerged is what might best be characterized as a trait, rather than an intentional, conception of 
individuality. The formal practices of school within which considerations of student individuality are inscribed appear to contribute to the identification of individuals as constituents of distinct categorical entities that can be differentiated from some norm. By "differentiated" we do not mean solely in terms of a focus on what might well be thought of as the tail end of a continuous distribution. The classroom goals and their origins, the pedagogies, the outcomes, and the assessment and reporting practices which were used to organize the presentation and discussion of the findings indicate the presence of an entirely different distribution from that used to characterize the collective. That is, the distinctions made between classes and individuals are more a matter of kind than of degree.

\section{Explanatory Factors: The Individual and Beyond}

Despite the theoretical paradox given by the simultaneous presence of the two folk pedagogies, such an inconsistency, at least in contexts of actual practice, is not altogether unusual and seems to find efficacy in managing the uncertain and ambiguous nature of teachers' professional worlds (Ashton \& Webb, 1986; Berlak \& Berlak, 1981; Doyle, 1986; Kagan, 1992). Such a milieu, experienced first as a student and later as a practitioner, proffers the empirical ingredients which give rise to what James (1830/1950), over a century ago, called "knowledge of acquaintance"; that is, the implicit knowledge we find exemplified in practice. Unlike scientific theories, the tacit and unreflective nature of these folk assumptions means that they are not logically coherent systems of statements but rather loosely connected ones (Calderhead, 1996; Huber \& Mandl, 1984; Pajares, 1992). As such, it is conceivable for opposing elements to be contained therein and consequently appear as so-called "knots" (Wagner et al., cited in Huber \& Mandl) in actual practice. Acker (1999) points out that educational research has, in its efforts to produce generalities, paid little attention to such idiosyncratic differences among teachers.

While we have considered the folk pedagogical paradox from the perspective of the individual teacher within a classroom, it would be shortsighted to ignore the broader context within which classroom practice is situated. In closing, we highlight certain macro-level conditions that we believe influence the experience of classroom teachers in locating the child in the curriculum. Specifically, we consider the extant environment of sociopolitical change, intensification of teaching, and a culture of deficit thinking as possible explanatory factors.

\section{Socio-Political Change}

Increasingly, the impact of globalization and the marketization of education has led many governments to attempt school reform by focusing on strategies of standardization in conjunction with powerful accountability measures (Apple, 2001; Ball, 1998). Unfortunately, few policy makers have acknowledged Sarason's (1990) belief that educational reform cannot merely address isolated or discrete components of a complex system, and many reform efforts have placed emphasis on standardization and accountability without fully accounting for educational context. The resulting pressure placed on classroom teachers and 
students to "make the grade" is enormous and, as a result, teachers often find themselves attempting to rationalize student outcomes. Within the context of the current political climate that insists "all children can learn", teachers seek to rationalize the sometimes problematic dynamic between students in the classroom and the expectations of the educational system. As we saw in the present study, teachers reconcile the disjoint between child and the curriculum by emphasizing individual student traits based on negative typologies.

\section{Intensification of Teaching}

Intensification, a prevailing phenomenon that asks teachers to do more in a short time and in ways that are often highly prescribed, causes teachers to question whether they have the time or the resources to ensure students learn the prescribed material with a high degree of understanding (Hargreaves, 1990). The professional judgment that tells teachers to slow down and address the individual needs of students who are failing to keep pace must be ignored, or the failure of these students somehow rationalized, if the expectations of the curriculum are to be met in the time allotted. As standardization of curricula and assessment become increasingly emphasized, teachers begin to regard tasks as highly particularized and specific to the educational context (i.e., curriculum) while more general competencies are disregarded or devalued (Stake, 2002). When intensification of standards results in an emphasis on high-stakes testing to the virtual exclusion of other forms of assessment, teachers feel pressure to reconceptualize how they understand teaching, student learning, and educational success. Definitions of what makes for a "good" student become increasingly narrowed and, as shown by the teachers in this study, teachers demonstrate a tendency to find good in certain students by referencing behavioral traits as opposed to academic achievement.

\section{The Culture of Deficit Thinking}

Teachers in this study constructed student diversity and individuality with an emphasis on trait ascription. In describing their students, we saw that they often referenced institutionally assigned labels or categories. Students were "LD", "ESL" or "ADHD" and as such, were seen as distinct from "the class." Some teachers revealed an assumption of homogeneity amongst members of particular groups so that the "ESL students" and the "LD kids" were assigned collective traits and needs. One teacher even generalized to the point of referencing "the nature of the Special Ed kid."

As we have argued, we do not believe that this conceptualization of individual students in trait terms is the result of an autonomous decision-making process on the part of teachers. Schools are public arenas (Olsen, 1997) wherein teachers' perceptions of students are mediated by a myriad of contextual factors (Wertsch, 1998). As we noted earlier, the labels used by educators to describe students who do not fit the dominant notions of success are, in fact, reflective of societal values and institutional conditions (Deschenes, Cuban, \& Tyack, 2001). Valencia (1997) argues that deficit thinking - the belief that students who fail do so because of some internal deficit or deficiency - has permeated current 
educational thought and practice, and is reflected in the way in which student success (or failure) is defined. The transmitters through which schools express the notion of deficit or difference vary depending upon the ideological and intellectual climate of the times but the message remains constant - namely, that the chief causes of failure exist within the individual.

Within school settings, deficit thinking continues to be used to explain the failure of certain groups of students. It fosters descriptions of behavior that emphasize pathology or dysfunction, and reinforces stereotypes of certain groups of students. Within this deficit-based context, endogenous factors are seen as explanatory of poor performance and teachers are told that unless intervention remediates the deficit, academic failure amongst certain groups is highly predictable. As we have seen, the pressure on teachers to rationalize student failure by the ascription of typologies is well established and growing.

As school boards face mounting pressure to service students in inclusive settings and to apply national standards assessments to special education students, there is increasing pressure on classroom teachers to meet highly diverse needs (Lipsky \& Gartner, 1996). Increasingly, educational discourse emphasizes notions of inclusivity and integration (Dyson, 2001) and many teachers find themselves with classrooms of students identified as "at risk" because their level of basic skills makes them unlikely to meet excellence standards (Margonis, 1992; McMahon, 2002). In the burgeoning culture of Identification, Placement and Review Committees (IPRCs), Individual Education Plans and the direct linkage of funding or services with identifiable needs, it is small wonder that teachers seek to find order in an increasingly complex situation. One may take, as an example, a recent decision by Ontario's Education Quality and Accountability Office to disallow extra time or accommodations on their provincial standardized tests unless students have been identified as special needs through the official special education identification procedure as opposed to a teacher's recommendation. A headline, in a local newspaper, reported one particular school board's reference to the "new rules" as the reason for a decline in their student test scores.

The type of educational climate that requires teachers to document children's weaknesses relative to a set of curricular standards not surprisingly fosters the adoption of a child-referenced stance that emphasizes the behavioral realm. In such a system teachers seek solace in the aforementioned paradoxical folk pedagogies as a way of rationalizing the tension between the child who has been entrusted to their care and the curriculum they are expected to teach.

Recognizing the reality of the contextual factors that engender this dynamic, we close with a suggestion that is the substance of our current research efforts. We have begun to think about the potential for locating the child in relation to the curriculum in ways that move beyond the extant "trait" conceptions of individuality reflected by the teachers' comments in this study. Specifically, we are drawn to the existing structural dynamic provided by the "typical" parentteacher interview. In theory, this particular type of interaction requires teachers to consider each child as separate from the class, and to identify and communicate their academic, social and emotional progress as discrete 
achievements in a formative and informative way. Furthermore, this potentially emotion-laden communication allows for and, in fact, requires teachers to supplement the formal and systemically-supported language of pedagogy, evaluation and assessment with the "doings" (Dewey, 1938) of the child. In this way, the structural and social dynamic of the parent-teacher interview offers the promise of helping teachers to locate the child in the curriculum in intentional rather than trait terms.

\section{References}

Acker, S. (1999). The realities of teachers' work: Never a dull moment. London: Cassell.

Apple, M. (2001). Educating the "right" way. New York: RoutledgeFalmer.

Applebee, A. N. (1996). Curriculum as conversation: Transforming traditions of teaching and learning. Chicago: The University of Chicago Press.

Ashton, P. T., \& Webb, R. B. (1986). Making a difference: Teachers' sense of efficacy and student achievement. New York: Longman.

Ball, S. (1998). Big policies, small world: An introduction to international perspectives in education policy. Comparative Education, 34(2), 119-130.

Baxter Magolda, M. (1992). Knowing and reasoning in college: Gender-related patterns in students' intellectual development. San Francisco: Jossey Bass.

Belenky, M., Clinchy, B., Goldberger, N., \& Tarule, J. (1986). Women's ways of knowing: The development of self, voice, and mind. New York: Basic Books.

Berlak, A. \& Berlak, H. (1981). Dilemmas of schooling: Teaching and social change. London: Methuen.

Brown, A. L., \& Campione, J. C. (1994). Guided discovery in a community of learners. In K. McGilly (Ed.), Classroom lessons: Integrating cognitive theory and classroom practice (pp. 229-270). Cambridge: Bradford Books/MIT Press.

Calderhead, J. (1996). Teachers: Beliefs and knowledge. In D. Berliner \& R. Calfee (Eds.), The handbook of educational psychology (pp. 709-725). New York: Macmillan.

Chandler, M., Boyes, M., \& Ball, L. (1990). Relativism and stations of epistemic doubt. Journal of Experimental Child Psychology, 50, 370-395.

Clay, M. (1996). Accommodating diversity in early literacy learning. In D. R. Olson \& N. Torrance (Eds.), The handbook of education and human development (pp. 202-224). Cambridge: Blackwell.

Deschenes, S., Cuban, L., \& Tyack, D. (2001). Mismatch: Historical perspectives on schools and students who don't fit them. Teachers College Record, 103, 525-547.

Dewey, J. (1902/1966). The child and the curriculum. Chicago: University of Chicago Press.

Dewey, J. (1938). Experience and education. New York: Collier Books.

Doyle, W. (1986). Classroom organization and management. In M. C. Wittrock (Ed.), Handbook of research on teaching (pp. 392-431). New York: Macmillan.

Dyson, A. (2001). Special needs in the twenty-first century: Where we've been and where we're going. British Journal of Special Education 28(1), 24-29.

Earl, L., \& Cousins, J. B. (1996). Classroom assessment: Changing the face; facing the change. Toronto: Ontario Public School Teachers' Federation.

Earl, L., \& Katz, S. (2000). Changing classroom assessment: Teachers' struggles. In N. Bascia \& A. Hargreaves (Eds.), The sharp edge of educational change (pp. 97-111). London: Routledge.

Earl, L., \& Katz, S. (2002). Leading schools in a data-rich world. In K. Leithwood \& P. Hallinger (Eds.), Second international handbook of educational leadership and administration (pp. 1003-1024). London: Kluwer.

Fullan, M. (1997). Notes from the Dean. Orbit, 28, 2.

Glaser, B., \& Strauss, A. (1967). The discovery of grounded theory: Strategies for qualitative research. Chicago: Aldine. 
Hacking, I. (1996). Normal people. In D. Olson \& N. Torrance (Eds.), Modes of thought. Cambridge, UK: Cambridge University Press.

Hargreaves, A. (1994). Changing Teachers, Changing Times: Teachers' Work and Culture in the Postmodern Age. Toronto: The Ontario Institute for Studies in Education Press.

Hargreaves, A., Earl, L., Moore, S., \& Manning, S. (2001). Learning to change: Teaching beyond subjects and standards. San Francisco: Jossey-Bass.

Heath, S. B. (1982). Questioning at school and at home: A comparative study. In G.

Spindler (Ed.), Doing the ethnography of schooling: Educational anthropology in action (pp. 102131). New York: Holt, Rinehart \& Winston.

Huber, G. L., \& Mandl, H. (1984). Access to teacher cognitions: Problems of assessment and analysis. In R. Holkes \& J. K. Olson (Eds.), Teacher thinking: A new perspective on persisting problems in education (pp. 58-70). Lisse, Netherlands: Swets.

James, W. (1830/1950). The principles of psychology. New York: Dover.

Kagan, D. M. (1992). Implications of research on teacher belief. Educational Psychologist, 27, 65-90.

Katz, S. (1998). Substituting the symbol for the experience: Exposing a fallacy in mathematics education. The Journal of Mathematical Behavior, 17, 405-410.

Katz, S. (2000). Competency, epistemology and pedagogy: Curriculum's holy trinity. The Curriculum Journal, 11, 133-144.

Katz, S. (2002). Reconnecting the child and the curriculum: Places of paradox. Curriculum and Teaching, 17, 5-20.

Katz, S., Earl, L., \& Olson, D. (2001). The paradox of classroom assessment: A challenge for the $21^{\text {st }}$ century. The McGill Journal of Education, 36, 13-26.

King, P., \& Kitchener, K. (1994). Developing reflective judgment: Understanding and promoting intellectual growth and critical thinking in adolescents and adults. San Francisco: JosseyBass.

Kuhn, D. (1999). A developmental model of critical thinking. Educational Researcher, 28, 16-26, 46.

Lipsky, D., \& Gartner, A. (1996). Inclusion, school restructuring, and the remaking of American society. Harvard Educational Review, 66, 762-96.

Margonis, F. (1992). The cooptations of "At Risk": Paradoxes of policy criticism. Teachers College Record, 94, 343-364.

McMahon, B. (2002). Beyond a discourse of deficit: The role of educational administrators in conceptions of risk and resiliency. Paper delivered at the $7^{\text {th }}$ Annual Values and Educational Leadership Conference, Toronto, Canada, October 3-5, 2002.

Olsen, L. (1997). Made in America. New York: New Press.

Olson, D. R. (1999). There are $\mathrm{x}$ kinds of learners in a single class: Diversity without individual differences. In J. Gaffney \& B. Askew (Eds.), Stirring the waters: A tribute to Marie Clay. Portsmouth, NH: Heinemann.

Olson, D. R., \& Bruner, J. S. (1996). Folk psychology and folk pedagogy. In D. R. Olson \& N. Torrance (Eds.), The handbook of education and human development (pp. 9-27). Cambridge: Blackwell.

Olson, D. R., \& Katz, S. (2001). The fourth folk pedagogy. In B. Torff \&R. J. Sternberg (Eds.), Understanding and teaching the intuitive mind: Student and teacher learning (pp. 243-263). Hillsdale, NJ: Erlbaum.

Pajares, F. (1992). Teachers' beliefs and educational research: Cleaning up a messy construct. Review of Educational Research, 62, 307-332.

Perry, W. (1970). Forms of intellectual and ethical development in the college years. New York: Holt, Rinehart \& Winston.

Polanyi, M. (1958). Personal knowledge. New York: Harper.

Rogoff, B., Matusov, E., \& White, C. (1996). Models of teaching and learning: Participation in a community of learners. In D. R. Olson \& N. Torrance (Eds.), The handbook of education and human development (pp. 388-414). Cambridge: Blackwell.

Sarason, S. B. (1990). The predictable failure of educational reform: Can we change course before it's too late? San Francisco: Jossey-Bass. 
Schommer, M. (1994). Synthesizing epistemological belief research: Tentative understandings and provocative confusions. Educational Psychology Review, 6, 293-320.

Stanovich, P., \& Jordan, A. (1998). Canadian teachers' and principals' beliefs about inclusive education as predictors of effective teaching in heterogeneous classrooms. The Elementary School Journal, 98, 221-238.

Stake, (2002). Teachers conceptualizing student achievement. Teachers and Tteaching: Theory and Practice, 8(3), 303-312.

Sternberg, R., \& Williams, W. (2003). Educational psychology. Toronto: Allyn \& Bacon.

Strauss, S. (1993). Teachers' pedagogical content knowledge about children's minds and learning: Implications for teacher education. Educational Psychologist, 28, 279-290.

Strauss, S. (1996). Confessions of a born-again constructivist. Educational Psychologist, 31, 1521.

Thomas, G. (1992). Effective classroom teamwork: Support or inclusion? London: Routledge.

Valencia, R. (1997). Conceptualizing the notion of deficit thinking. In R. Valencia (Ed.), The evolution of deficit thinking. London: Falmer Press.

Wertsch, J. (1998). Mind as action. New York: Oxford University Press.

Wilson, R. (1996). Assessing students in classrooms and schools. Toronto: Allyn \& Bacon.

Windschitl, M. (2002). Framing constructivism in practice as the negotiation of dilemmas: An analysis of the conceptual, pedagogical, cultural, and political challenges facing teachers. Review of Educational Research, 72, 131-175. 